\title{
Rodzina onkogennych kinaz PIM — potencjalne cele terapeutyczne w nowotworach układu krwiotwórczego i chłonnego
}

\author{
Maciej Szydłowski, Przemysław Juszczyński
}

Do rodziny kinazy serynowo-treoninowych PIM należą trzy homologiczne białka PIM1, PIM2 i PIM3 regulujące aktywność szerokiego spektrum substratów i wpływające na procesy transkrypcji, translacji, proliferacji, apoptozy, metabolizmu i migracji komórek. Wpływ na te procesy powoduje, iż kinazy PIM stanowią istotne ogniwo patogenezy nowotworów układu krwiotwórczego, chłonnego, a także wielu nowotworów litych. Kinazy PIM wzmacniają ponadto i konsolidują działanie innych, silnych onkogenów - w tym c-MYC i BCL6. W części nowotworów nadekspresja kinaz PIM stanowi niekorzystny czynnik rokowniczy. Kinazy PIM nie wymagają modyfikacji potranslacyjnych dla pełnej aktywności, zatem ekspresja białka oznacza aktywność enzymatyczną. Unikalna struktura kinaz tej rodziny pozwala na opracowanie swoistych inhibitorów, a łagodne konsekwencje biologiczne genetycznego wyłączenia kinaz PIM u zwierząt pozwalają przypuszczać, że farmakologiczne zahamowanie ich aktywności nie będzie związane $z$ istotnymi działaniami niepożądanymi. W ostatnich latach opracowano wiele inhibitorów kinaz PIM. Wykazują one aktywność w stosunku do linii komórkowych $\mathrm{AML}, \mathrm{DLBCL}, \mathrm{MCL}, \mathrm{CLL}, \mathrm{PCM}, \mathrm{CHL}$ oraz w modelach in vivo, a część z nich trafiła do badań klinicznych. Unikalny charakter regulacji aktywności tych kinaz powoduje również, że w warunkach klinicznych trudno określić, jaki poziom ekspresji kinazy PIM jest istotny patogenetycznie. Identyfikacja racjonalnych biomarkerów dla inhibitorów kinaz PIM stanowi obecnie największe wyzwanie, które musi znaleźć swe rozwiązanie przed wprowadzeniem inhibitorów kinaz PIM do klinik hematoonkologicznych.

\section{Family of the oncogenic PIM kinases: potential targets in lymphoid and myeloid malignancies}

The PIM family of serine-threonine kinases comprises three homologous proteins, PIM1, PIM2 and PIM3, regulating a broad spectrum of cellular substrates. They also tune important processes such as translation, transcription, proliferation, apoptosis, metabolism and migration. In addition, PIM kinases augment and consolidate the oncogenic potential of certain strong oncogenes, such as C-MYC and BCL6. PIM kinases play an important pathogenetic role in multiple haematological and solid malignancies, and in some tumours their expression is associated with adverse prognosis. PIM kinases do not require post-translational modifications for their activity. Mild phenotypes of triple knockout mice, lacking all PIM isoforms suggest that PIM kinases are good, druggable targets and their pharmacological inhibition will be well tolerated. The unique structure-function relationship facilitates design of specific small molecule inhibitors. Multiple such compounds targeting PIM kinases have been identified. PIM inhibitors exhibit promising activity against in vitro and in vivo models of multiple lymphoid and myeloid malignancies. However, given the unique mechanism of PIM kinases regulation, definition of pathogenetically important level of PIM expression is not feasible, and a rational, clinically useful biomarker has not been yet developed. Identification of such biologically and clinically relevant biomarkers is the major challenge hampering successful translation of basic knowledge on PIM biology to clinically available drugs.

NOWOTWORY Journal of Oncology 2016; 66, 1:1-11

Słowa kluczowe: kinazy PIM, terapia celowana, ostra białaczka szpikowa, przewlekła białaczka limfocytowa, chłoniaki, szpiczak plazmocytowy

Key words: PIM kinases, targeted therapy, acute myelogenous leukemia, non-Hodgkin lymphoma, chronic lymphocytic leukemia, plasma cell myeloma

Zakład Hematologii Eksperymentalnej Instytut Hematologii i Transfuzjologii w Warszawie 


\section{Wprowadzenie}

Geny Pim-1, -2 i -3 (the proviral insertion site in Moloney murine leukemia virus) kodują trzy kinazy serynowo-treoninowe, PIM1, PIM2 oraz PIM3, charakteryzujące się wysokim stopniem homologii oraz szerokim spektrum regulowanych substratów, poprzez które kinazy te wpływają na kluczowe procesy komórkowe, takie jak przeżywalność, proliferacja, apoptoza, cykl komórkowy i wzrost. Fizjologiczna rola kinaz PIM dotyczy regulacji proliferacji komórek w odpowiedzi na czynniki mitogenne, w tym czynniki wzrostu [1]. Pierwszą kinazę tej rodziny, PIM1, zidentyfikowano w latach 80. ubiegłego stulecia. W mysim modelu chłoniaka indukowanego wirusem białaczki Moloney (Moloney Murine Leukaemia Virus - MMLV) obserwowano częste insercje MMLV do locus Pim1, prowadzące do indukcji ekspresji tej kinazy w komórkach nowotworowych [2]. Kinazy Pim 2 i Pim3 zidentyfikowano także w eksperymentach z użyciem mutagenezy insercyjnej MMLV. W badaniach tych obserwowano ponadto występowanie zjawiska kompensacji, polegającego na włączeniu ekspresji kinaz PIM2 lub PIM3 odpowiednio

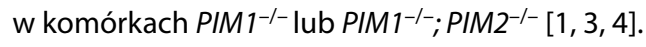

Onkogenny charakter aktywności Pim1 potwierdzony został następnie przy użyciu myszy z transgenem E $\mu$-pim-1, powodującym zależną od sekwencji wzmacniającej transkrypcję loci immunoglobulinowych $(E \mu)$ oraz wirusowej sekwencji LTR, nadekspresję kinazy Pim1 w limfocytach T i B oraz rozwój spontanicznych chłoniaków T-komórkowych [5]. Stosunkowo niska częstość występowania tych nowotworów u myszy E $\mu$-pim-1 oraz długi okres latencji potrzebny do ich rozwoju wskazuje na zależność potencjału onkogennego Pim1 od innych, współwystępujących zaburzeń. We wszystkich chłoniakach indukowanych MMLV obserwowano nadekspresję onkogennego czynnika c-Myc (v-myc avian myelocytomatosis viral oncogene homolog) [6], co wskazywało na współdziałanie tych czynników w rozwoju nowotworu. Kooperacja obu białek w patogenezie chłoniaków została potwierdzona w modelu mysim poprzez wywołanie w komórkach limfoidalnych jednoczesnej nadekspresji Pim1 i c-Myc, wynikającej z obecności transgenów

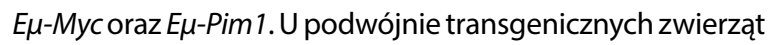

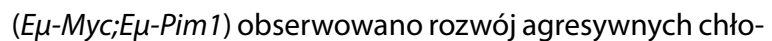
niaków już w fazie rozwoju płodowego lub we wczesnym okresie po narodzeniu [7]. Endogenna aktywność kinaz Pim odgrywa istotną rolę dla zależnej od c-Myc onkogenezy, a jej zahamowanie poprzez ablację izoform Pim1 i 2 lub wszystkich trzech izoform Pim powoduje znaczące wydłużenie czasu latencji białaczek/chłoniaków B-komórkowych indukowanych przez E $\mu$-Myc [4].

W odróżnieniu od wczesnych komórek prekursorowych, w dojrzałych limfocytach IgM+ nie obserwowano transformacji nowotworowej indukowanej koekspresją Pim i c-Myc [8]. Obserwacja ta nie wyklucza jednak roli, jaką współdziałanie obu onkogenów może odgrywać dla biologii, agresywności i cech klinicznych nowotworów z dojrzałych limfocytów $B$.

Poza czynnikiem c-MYC kinazy PIM mogą współdziałać i potęgować aktywność innych onkogenów, między innymi BCL6 (B-cell leukemia/lymphoma 6) lub ABL ( $\mathrm{BBL}$ proto-oncogene 1, non-receptor tyrosine kinase) [9, 10]. W mysich chłoniakach B- i T-komórkowych indukowanych nadekspresją Bcl6, Pim 1 został zidentyfikowany jako najczęściej koaktywowany gen w wyniku mutagenezy insercyjnej, a nadekspresję kinazy PIM1 obserwowano we wszystkich badanych ludzkich chłoniakach B-komórkowych wykazujących ekspresję BCL6 [8]. Ekspresja kinaz Pim1 i Pim2 jest konieczna dla transformacji nowotworowej związanej z aktywnością onkogenu $A B L$ w mysich komórkach prekursorowych, ponieważ ablacja obu kinaz w komórkach pre-B, do których wprowadzono onkogen $A B L$, nie powodowała niezależnej od czynników wzrostu proliferacji oraz transformacji [9]. Zachowanie ekspresji kinazy Pim1 lub Pim2 wystarczało natomiast do transformującego efektu $A B L$ na te komórki, co wskazuje na redundancję w funkcji pomiędzy Pim1 i Pim2 w tym zakresie [9].

Nadekspresję kinaz PIM obserwowano w licznych nowotworach układu krwiotwórczego, chłonnego oraz niektórych typach guzów litych. Ze względu na stale zwiększającą się ilość dowodów wykazujących istotną rolę aktywności PIM w patogenezie nowotworów, w ostatnich latach zintensyfikowano badania mające na celu określenie mechanizmów patogenetycznych powiązanych z aktywnością tych kinaz oraz opracowano liczne małocząsteczkowe inhibitory PIM, podlegające w chwili obecnej walidacji przedklinicznej i klinicznej.

\section{Regulacja ekspresji i aktywności kinaz PIM}

U człowieka geny kodujące kinazy PIM zlokalizowane są na chromosomie 6 (PIM1), chromosomie X (PIM2) oraz chromosomie 22 (PIM3) [1]. Geny PIM złożone są z sześciu eksonów oraz transkrybowane są do matrycowych RNA zawierających duże, niekodujące regiony 5 ' oraz 3'. Sekwencje destabilizujące AUUA występujące w regionach 3' wpływają na szybką degradację mRNA, natomiast wysoka zawartość GC w regionach 5' powoduje, iż transkrypty PIM należą do tzw. „słabych” transkryptów, których translacja zależna jest od czapeczki 5'-m ${ }^{7} G[10,11]$. Usunięcie regionu 5 ' bogatego wGCPIM1 powoduje znaczne zwiększenie ekspresji białka [12].

PIM 1 i PIM 2 wykazują 61\%, a PIM1 i PIM3 - 77\% homologii w zakresie sekwencji aminokwasowej [1]. Kinazy rodziny PIM posiadają wysoce konserwowaną domenę katalityczną, ale w swojej strukturze nie posiadają typowych dla innych kinaz sekwencji regulatorowych [13, 14]. W konsekwencji - kinazy PIM nie wymagają modyfikacji potranslacyjnych warunkujących ich aktywność katalityczną. Ich aktywność jest zatem regulowana jedynie na poziomie transkrypcji, translacji i stabilności mRNA i białka. 


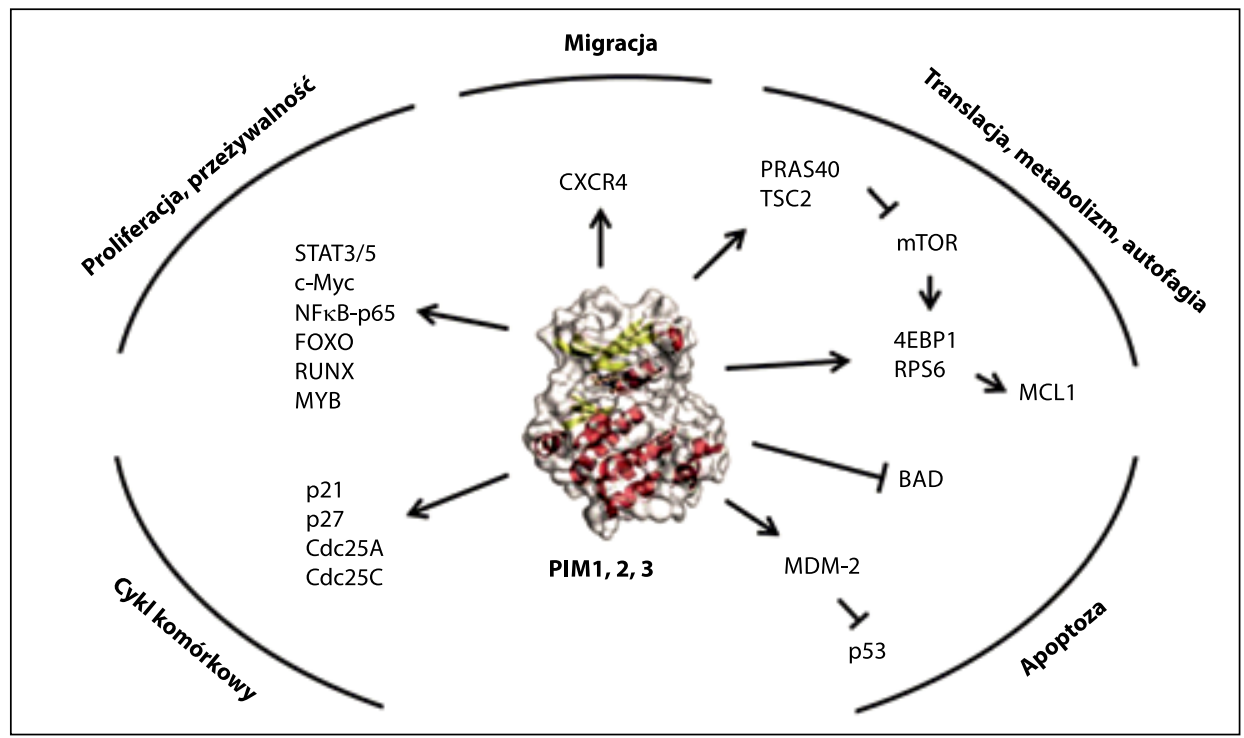

Rycina 1. Mechanizmy patogenetyczne związane z aktywnością kinaz PIM

Kinazy PIM ulegają ekspresji wskutek pobudzenia komórek przez czynniki wzrostu i cytokiny. W komórkach limfoidalnych ekspresję kinaz tej rodziny indukują m.in. cytokiny rodziny TNF: BAFF (B-cell activating factor), APRIL (a proliferation inducing ligand) i CD40, które prowadzą do aktywacji czynników transkrypcyjnych rodziny STAT (signal transducer and activator of transcription) i NF $\kappa \mathrm{B}$ [15-19]. Stopień wzbudzenia transkrypcji poszczególnych kinaz PIM i udział określonych czynników transkrypcyjnych wykazuje jednak dużą zmienność w zależności od typu komórek. Wzbudzenie osi JAK/STAT i/lub NF $\kappa$ B i nadekspresja kinaz PIM może wynikać z konstytutywnej aktywności receptorów zależnych od mutacji aktywujących (np. FLT3-ITD - fms-related tyrosine kinase 3 - internal tandem duplication), od interakcji z mikrośrodowiskiem lub od obecności białek fuzyjnych, w tym BCR-ABL1 [20-22]. Transkrypcję tych kinaz może indukować również czynnik KLF5 (Kruppel-like factor 5) w odpowiedzi na uszkodzenia DNA, co prowadzi do antyapoptotycznej aktywności PIM w uszkodzonych komórkach [23]. W komórkach chłoniaków z rearanżacją c-MYC locus kinazy PIM3 jest aktywowany przez ten czynnik transkrypcyjny [24].

Jak wskazano powyżej, struktura kinaz rodziny PIM warunkuje ich konstytutywną aktywność, niewymagającą modyfikacji potranslacyjnych. Modyfikacje takie mogą jednak wpływać na stabilność białka. Rolę taką przypisuje się fosforylacji tyrozyny Y218 PIM1 przez kinazę ETK [25]. Kinaza PIM1 może ponadto ulegać autofosforylacji (seryna S8), ale funkcjonalne konsekwencje tej modyfikacji pozostają niewyjaśnione [26]. Stabilność kinaz PIM jest regulowana głównie poprzez ich proteasomalną degradację [27]. Sprzyja temu m.in. wiązanie i defosforylacja PIM1 i PIM3 przez fosfatazę PP2A (protein phosphatase 2A) [28, 29]. Za stabilizację białka PIM1 odpowiada natomiast białko opiekuńcze HSP90 (heat shock protein 90) [30]. Zahamowanie jego aktywności swoistym inhibitorem geldanamycyną prowadzi do szybkiej proteasomalnej degradacji PIM1 [27, 30].

\section{Wpływ kinaz PIM na aktywność czynników transkrypcyjnych}

Kinazy PIM regulują aktywność niektórych czynników transkrypcyjnych, w tym c-MYC, MYB ( $v$-myb avian myeloblastosis viral oncogene homolog) RUNX1 (runt-related transcription factor 1), RUNX3, FOXO1 (Forkhead box O), FOXO3a i NF $\kappa$ B [31-37] (ryc. 1). Kinazy PIM1 i PIM2 zwiększają stabilność białka c-MYC poprzez fosforylację odpowiednio seryny S62 i S329 oraz S293 [35, 38]. Modyfikacje te zapobiegają ubikwitynacji i degradacji proteasomalnej c-MYC i powodują zwiększenie transkrypcji zależnej od c-MYC i jego potencjału onkogennego. Białko c-MYC poprzez bezpośrednie wiązanie PIM1 rekrutuje ponadto tę kinazę w obręb sekwencji E-box, gdzie fosforyluje ona serynę S10 histonu H3 (H3S10) [39]. Modyfikacja ta powoduje rekrutację $m$.in. acetylotransferazy MYST (KAT8 - K(lysine) acetyltransferase 8), acetylację H4K16, a następnie dokowanie BRD4 (bromodomain containing 4) i kompleksu p-TEFb (positive transcription elongation factor $b$ ), który fosforyluje serynę S2 polimerazy RNA II, powodując jej pełną aktywację transkrypcyjną (pause release) $[40,41]$. Ocenia się, że ten mechanizm zwiększa aktywność transkrypcyjną c-MYC o ok. 20\% [39].

Kinazy PIM wpływają również na aktywność czynników transkrypcyjnych rodziny STAT. PIM wiążą się bezpośrednio z czynnikiem STAT5 i fosforylują S731, leżącą w C-końcowym obszarze wpływającym na aktywność transkrypcyjną tego czynnika [38]. Zahamowanie kinaz PIM powoduje głębokie zmniejszenie fosforylacji S371, ale ma słabszy wpływ na 
fosforylację Y694/699, zależną od kinaz JAK2/TYK2, i konstytutywnie aktywnych kinaz tyrozynowych (np. BCR-ABL1, FLT3-ITD). Mechanizm ten wskazuje na mechanizm dodatniego sprzężenia zwrotnego między ekspresją kinaz PIM, regulowanych transkrypcyjnie przez STAT5, a aktywnością tego czynnika transkrypcyjnego. Kinaza PIM3 zwiększa ponadto aktywność czynnika STAT3 poprzez fosforylację tyrozyny Y705 i wpływa na jego aktywność w komórkach nowotworowych [42]. Poprzez wpływ na czynniki transkrypcyjne STAT kinazy PIM mogą modulować ekspresję/ /aktywność wielu białek działających antyapoptotycznie, (BCL-xL, surwiwina) i powodujących oporność na chemioterapeutyki (HIF1 $\alpha$, MDR-1) [43].

PIM1 wpływa również na stabilizację podjednostki RelA/ /p65 NF $\kappa$ B przez fosforylację S276 [33, 34]. Za nasilenie aktywności NF $\kappa$ B może również odpowiadać kinaza PIM2, zdolna do fosforylacji onkogennej kinazy serynowo/treoninowej Cot, prowadząc do zwiększenia jej aktywności, a w konsekwencji do zwiększenia jądrowej obecności heterodimerów p65/p50 kosztem homodimerów p50 i wzmożenia ekspresji genów zależnych od NF $\kappa$ B [33].

Miejsca fosforylacji czynnika transkrypcyjnego FOXO3a (T32, S253), typowo modyfikowane przez kinazę AKT ( $v$-akt murine thymoma viral oncogene homolog 1), leżą w obrębie regionów częściowo odpowiadających sekwencji consensus dla kinaz PIM. Fosforylacja FOXO3a przez AKT lub PIM powoduje eksport tego czynnika transkrypcyjnego z jądra komórkowego i wyłączenie jego aktywności transkrypcyjnej [32].

\section{Wpływ na translację i metabolizm komórek}

Kinazy PIM (głównie PIM2) wykazują funkcjonalną homologię ze szlakiem PI3K/AKT/mTOR i dzielą z nim niektóre substraty odpowiedzialne za regulację metabolizmu komórkowego i translacji, ale nie podlegają tym samym mechanizmom regulacyjnym co mTOR (mammalian target of rapamycin) [44]. Z tego względu, aktywność PIM2 może częściowo kompensować utratę aktywności mTOR (ryc. 1) [17]. Funkcjonalną homologię osi PI3K/AKT/mTOR i PIM2 potwierdzają obserwacje dotyczące limfocytów B z wyłączoną ekspresją kinazy PIM2, w których działanie IL-4 i BAFF w obecności rapamycyny nie jest w stanie zapobiec ich apoptozie $[15,45]$. Ekspresja PIM2 w komórkach B jest zatem niezbędna dla działania B-komórkowych czynników wzrostu w sytuacji, gdy aktywność mTOR ulega wyłączeniu. Biochemiczną podstawa tych zjawisk jest niepoddająca się hamowaniu rapamycyną, zależna od kinazy PIM2 fosforylacja T37, T46, S65 białka 4E-BP1 (eukaryotic translation initiation factor $4 E$ binding protein 1) [13]. Fosforylowany czynnik 4E-BP1 oddysocjowuje od białka EIF4E (eukaryotic translation initiation factor $4 E$ ), odpowiedzialnego za zależną od czapeczki 5'-7mG mRNA indukcję translacji tzw.,,słabych” transkryptów [46]. Należą do nich białka odpowiedzialne za progresję cyklu komórkowego (cyklina D3), antyapop- totyczne białko MCL-1 (myeloid cell leukemia 1) z rodziny BCL2, c-MYC oraz same kinazy PIM $[12,46,47]$.

Zbliżone spektrum substratów kinaz AKT/mTOR i kinaz PIM (w tym głównie PIM2) tłumaczy funkcjonalną homologię tych białek i wpływ na podobne procesy komórkowe — w tym metabolizm białek i translację. Homologia ta może również tłumaczyć wpływ kinaz PIM na autofagię. Autofagia stanowi odpowiedź komórek na różnego rodzaju stres, w tym stres metaboliczny (np. głodzenie), którego kluczowym regulatorem jest kinaza mTOR [48]. Zahamowanie mTOR (wskutek głodzenia lub działania rapamycyny) powoduje indukcję autofagii. Kinazy PIM1 i PIM2 hamują aktywność mTOR poprzez wpływ odpowiednio na białko PRAS40 (Thr 246) i TSC2 (Ser 1798) [49, 50]. Fosforylacja PRAS40 (proline rich AKT substrate 40) przez PIM1 powoduje oddysocjowanie tego białka od mTORC1 i aktywację mTORC1. Fosforylowane przez PIM2 lub AKT białko TSC2 (tuberous sclerosis) pełni funkcję aktywatora GTPazy (GAP, GTPase activating protein) dla białka RHEB (Ras homolog enriched in brain). Włączenie GTPazy RHEB hamuje jej zdolność do aktywacji mTORC1. W konsekwencji, wskutek fosforylacji TSC2 przez PIM2, aktywność mTOR ulega zahamowaniu. Po farmakologicznym zahamowaniu kinaz PIM w szpiczakowych plazmocytach obserwuje się indukcję procesu autofagii prowadzącą do śmierci komórek [51].

\section{Wpływ na migrację komórek}

Krwiotwórcze komórki macierzyste zwierząt pozbawionych kinaz PIM charakteryzują się obniżoną zdolnością do zasiedlania nisz szpikowych [52]. Wyłączenie aktywności kinaz PIM upośledza również zdolność do migracji i chemotaksji komórek nowotworowych. Kinaza PIM1 fosforyluje S339 wewnątrzkomórkowej domeny receptora chemokiny SDF1 (stromal cell derived factor 1), białka CXCR4 (chemokine [C-X-C motif] receptor 4) [53]. Modyfikacja ta stabilizuje białko i zwiększa jego powierzchniową ekspresję. Genetyczne bądź farmakologiczne wyłączenie kinaz PIM powoduje zmniejszenie ekspresji receptora CXCR4, mniejsze natężenie wewnątrzkomórkowego sygnału wyzwalanego przez wiązanie SDF1 oraz obniżenie zdolności migracyjnych komórek w gradiencie tej chemokiny $[53,54]$. Obok wpływu na adhezję i migrację komórkową oś SDF1-CXCR4 wywiera plejotropowe efekty na białaczkowe komórki macierzyste, obejmujące regulacje ich proliferacji i różnicowania, a inhibitory CXCR4 wykazują działanie przeciwbiałaczkowe in vitro, in vivo i w warunkach badań klinicznych [55, 56]. Wpływ kinaz PIM1 na działanie CXCR4 może zatem pośrednio oddziaływać na charakterystykę białaczkowych komórek macierzystych.

Kinazy PIM wpływają ponadto na adhezję, chemotaksję i zdolności migracyjne komórek w mechanizmach niezależnych od CXCR4, obejmujących m.in. wpływ na ekspresję receptora czynnika wzrostu hepatocytów, białka MET oraz 
aktywność czynnika transkrypcyjnego NFATc (nuclear factor of activated T cells, cytoplasmic, calcineurin dependent 1) $[57,58]$.

\section{Wpływ kinaz PIM na cykl komórkowy}

Oprócz zwiększenia translacji białek odpowiedzialnych za progresję cyklu komórkowego kinazy PIM wpływają na aktywność białek bezpośrednio i sprzyjają proliferacji. PIM1 fosforyluje Cdc25A (cell division cycle 25A), prowadząc do zwiększenia aktywności tej fosfatazy i promocji cyklu na etapie G1/S (ryc. 1) [59, 60]. Podobny efekt na punkt kontrolny G1/S ma fosforylacja i inaktywacja przez PIM1 inhibitorów kinaz cyklinozależnych p21Cip1/Waf1 (CDKN1A - cyclin-dependent kinase inhibitor 1A) [32, 61]. Kinazy PIM wpływają również na aktywność inhibitora p27 (CDKN1B), fosforylując jego T157 i T198 i powodując jego proteasomalną degradację [32]. Aktywność p27 jest regulowana przez kinazy PIM również pośrednio, poprzez zmniejszenie transkrypcji genu zależną od inaktywacji czynników transkrypcyjnych FOXO1 i FOXO3a [32].

\section{Wpływ kinaz PIM na apoptozę}

Nadekspresja kinaz PIM w modelach zwierzęcych i w ludzkich liniach komórkowych ma charakter antyapoptotyczny. Kinazy tej rodziny wpływają na translację i aktywność białek pro- i antyapoptotycznych rodziny BCL2, w tym BAD (BCL2-associated agonist of cell death) i MCL1. Proapoptotyczna funkcja BAD zależy od stanu fosforylacji trzech reszt serynowych (S112, S135 i S155) [62]. Za ich fosforylację odpowiadają kinazy indukowane przez czynniki wzrostu, w tym wszystkie izoformy kinaz PIM [13, 63-65]. Fosforylacja BAD powoduje oddysocjowanie $i$ uwolnienie antyapoptotycznych białek BCL2 i BCL-XL1 oraz relokalizację BAD z mitochondrium do cytozolu [62]. Fosforylacja S155 BAD powoduje ponadto indukcję glukokinazy i nasilenie glikolizy, zatem stanowi ona molekularny „przełącznik” między proapoptotycznym i metabolicznym działaniem BAD [66]. Kinaza PIM1 wpływa ponadto na szlak p53 poprzez fosforylacje białka MDM2 (MDM2 proto-oncogene, E3 ubiquitin protein ligase), ligazy E3 ubikwityny dla p53. PIM1 fosforyluje Ser166 i Ser186 MDM2 i zwiększa ilość MDM2 w komórce, co prowadzi do zwiększenia stopnia ubikwitynacji p53 [67]. Antyapoptotyczne działanie kinaz PIM wynika również z mechanizmów pośrednich, m.in. wpływu na aktywność FOXO3a i NF $\kappa$ B i transkrypcję białek regulowanych przez te czynniki.

\section{Kinazy PIM jako cel terapeutyczny}

Z uwagi na regulację fundamentalnych procesów biologicznych warunkujących wzrost i przeżycie komórek nowotworowych oraz współdziałanie z innymi onkogenami kinazy PIM budzą duże zainteresowanie jako cel terapeutyczny. Wyłączenie (knockout) kinaz PIM ma niewielki wpływ na fenotyp zwierząt modelowych [52]. W przypadku PIM1 wyłączenie aktywności tej kinazy powoduje defekt transdukcji sygnału IL-7 i zaburzenia różnicowania komórek pre-B w szpiku kostnym $[68,69]$. Komórki macierzyste pozbawione PIM1 wykazywały obniżoną zdolność do repopulacji nisz szpikowych u napromienionych zwierząt biorców [53]. Myszy pozbawione PIM2 wykazują obniżony poziom aktywacji limfocytów T w obecności rapamycyny, a wyłączenie kinazy PIM3 powoduje zaburzenia tolerancji glukozy $[45,70]$. Myszy pozbawione wszystkich trzech izoform PIM charakteryzują się niższą liczbą płytek, hipochromią erytrocytów, a także zmniejszonymi rozmiarami ciała i obniżoną odpowiedzią komórek na działanie czynników wzrostu, w porównaniu ze zwierzętami kontrolnymi [10, 52]. Krwiotwórcze komórki macierzyste zwierząt PIM1/2/3-/wykazywały ponadto obniżoną zdolność tworzenia kolonii, repopulacji szpiku i odtwarzania hemopoezy u napromienionych zwierząt syngenicznych [52]. Obserwacje te wskazują na istotną fizjologiczną rolę kinaz PIM w biologii hematopoetycznych komórek krwiotwórczych, obejmującą wpływ na ich ekspansję, różnicowanie, samoodnowę i zdolności repopulacyjne. Myszy z wyłączonymi genetycznie kinazami rodziny PIM pozostająjednak płodne i żywotne, a brak głębokich patologii narządowych u zwierząt pozbawionych tych kinaz wskazuje, że przewlekłe stosowanie inhibitorów PIM nie będzie powodowało znaczących działań niepożądanych [10].

Struktura kinazy PIM1 obejmuje N-końcową pętlę bogatą w glicynę (aminokwasy 44-52) oraz C-końcową pętlę aktywacyjną (aminokwasy 186-210), połączone elastycznym regionem zawiasowym (hinge region), a miejsce aktywne enzymu jest umiejscowione w bruździe na styku obu pętli [43, 71]. Pętla aktywacyjna, przez oddziaływania polarne, nawet przy braku fosforylacji, stabilizuje PIM w aktywnej konformacji, co tłumaczy konstytutywną aktywność tych kinaz. O ile kinazy PIM wykazują strukturalną homologię z innymi kinazami serynowo-treoninowymi, unikalna struktura regionu zawiasowego (prolina 123 tego regionu oraz przylegające aminokwasy) i inna niż w innych kinazach przestrzenna konfiguracja kieszeni wiążącej ATP pozwala na opracowanie swoistych dla rodziny PIM inhibitorów małocząsteczkowych $[43,71]$. W literaturze raportowano kilkaset związków z różną selektywnością hamujących poszczególne izoformy lub wszystkie kinazy PIM [43]. Ze względu na funkcjonalną redundancję izoform kinaz PIM, uwarunkowaną zbliżonym spektrum substratów, klinicznie użyteczny inhibitor powinien wykazywać aktywność wobec wszystkich trzech białek tej rodziny. Opracowanie takiej cząsteczki, działającej jako ATP-kompetytywny inhibitor pan-PIM, w praktyce może jednak stanowić problem, z uwagi na zróżnicowanie stałych dysocjacji ATP dla PIM1,2 i 3 (odpowiednio $\mathrm{K}_{\mathrm{m}}=400 \mu \mathrm{M} / \mathrm{L}$, $4 \mu \mathrm{M} / \mathrm{L}$ i $40 \mu \mathrm{M} / \mathrm{L}$ ) [72]. Kinaza PIM2 wiąże ATP najsilniej, a zatem jej pełne zahamowanie wymaga wysoce aktywnego 
Tabela 1. Inhibitory kinaz PIM w badaniach przedklinicznych i klinicznych

\begin{tabular}{|c|c|c|}
\hline Związek (producent) & Struktura & Stan badań \\
\hline $\begin{array}{l}\text { SGI-1776 } \\
\text { (Supergen/Astex Pharmaceuticals) }\end{array}$ & & $\begin{array}{l}\text { Zakończone/przerwane badania fazy I/II w chłoniakach, } \\
\text { raku prostaty i białaczkach szpikowych z powodu } \\
\text { toksyczności (wydłużenie QTc) }\end{array}$ \\
\hline AZD1208 (Astra Zeneca) & & $\begin{array}{l}\text { AML (NCT01489722), faza I } \\
\text { Guzy lite i chłoniaki, (NCT01588548), faza I }\end{array}$ \\
\hline LGH447 (Novartis) & Nie ujawniono & $\begin{array}{l}\text { AML, MDS: NCT02078609, faza I } \\
\text { PCM: NCT01456689, faza I } \\
\text { PCM: NCT02144038, faza I/II } \\
\text { Nowotwory hematologiczne: NCT02160951, faza I }\end{array}$ \\
\hline INCB053914 (Incyte) & Nie ujawniono & Faza I/II, zaawansowane nowotwory: NCT02587598 \\
\hline LGB321 (Novartis) & & Badania przedkliniczne \\
\hline $\begin{array}{l}\text { SMI-4a, } \\
\text { Medical University of South } \\
\text { Carolina }\end{array}$ & & Badania przedkliniczne \\
\hline CX-6258, Cylene & & Badania przedkliniczne \\
\hline SLV B489 (Selvita) & Nie ujawniono & Badania przedkliniczne \\
\hline
\end{tabular}

związku, zdolnego do kompetycji i wyparcia ATP z kieszeni wiążącej ATP w PIM2 pomimo wysokiego komórkowego stężenia ATP (1-10 mM/L - 250-2500, przekraczającego stałą dysocjacji ATP dla PIM2) [72]. Wyłączenie pojedynczej izoformy powoduje ponadto kompensacyjny wzrost ekspresji dwóch pozostałych izoform, zatem selektywna inhibicja pojedynczych izoform nie jest strategią o racjonalnych podstawach. Większość opracowanych inhibitorów pan-PIM jest obecnie na etapie badań przedklinicznych, ale część z nich jest w trakcie badań klinicznych wczesnych faz (tab. I).

\section{Inhibicja kinaz PIM w nowotworach układu krwiotwórczego}

Spośród nowotworów mieloidalnych wysoką ekspresją kinaz PIM charakteryzują się przede wszystkim przewlekła białaczka szpikowa (CML — chronic myelogenous leukemia) oraz ostre białaczki szpikowe (AML - acute myelogenous leukemia) (tab. II) [38, 71-74]. Nadekspresję PIM obserwuje się w ok. 30\% AML. Szczególnie wysoką ekspresję obserwowano u chorych z rearanżacją MLL oraz z mutacjami aktywującymi FLT3 $[20,75,76]$. W pierwszym przypadku indukcja ekspresji tych kinaz wynika z epigenetycznej aktywacji ekspresji czynnika transkrypcyjnego HOXA9 (homeobox A9), wpływającego z kolei na PIM [75]. W komórkach FLT3-ITD+ do indukcji kinaz PIM prowadzi natomiast aktywność czynników transkrypcyjnych STAT, wywołana obecnością aktywowanego mutacją receptora [38]. Ekspresję kinaz PIM indukują również mutacje aktywujące V617F JAK2 (Janus tyrosine kinase 2) oraz białko fuzyjne BCR-ABL1, w obu przypadkach w mechanizmie zależnym od czynników STAT [77-79]. Kinazy PIM w tych nowotworach stanowią ważne ogniwo patogenetyczne i istotny element efektorowy tych 
Tabela II. Nadekspresja kinaz PIM w nowotworach układu chłonnego i krwiotwórczego

\begin{tabular}{|c|c|c|c|}
\hline Choroba & Gen & Znaczenie kliniczne & Piśmiennictwo \\
\hline CLL & PIM1, PIM2 & Ekspresja PIM2 wyższa u chorych w wyższym stadium zaawansowania i opornych na I linię leczenia & {$[87,90,91]$} \\
\hline $\mathrm{MCL}$ & PIM1, PIM2 & $\begin{array}{l}\text { Ekspresja podwyższona w fazie blastycznej MCL. } \\
\text { Niekorzystne rokowanie }\end{array}$ & $\begin{array}{l}{[16,85]} \\
{[92]}\end{array}$ \\
\hline DLBCL & $P I M 1 / 2 / 3$ & Wyższa ekspresja w podtypie ABC. Wysoka ekspresja PIM2 w ABC-DLBCL wiąże się z krótszym OS i PFS & [93] [84] \\
\hline $\mathrm{FL}$ & $P I M 1 / 2 / 3$ & Niekorzystne rokowanie & {$[80]$} \\
\hline PMBCL & PIM1 & Nie określono & {$[94]$} \\
\hline $\mathrm{cHL}$ & $P I M 1 / 2 / 3$ & Nie określono & {$[89]$} \\
\hline AML & $P I M 1 / 2 / 3$ & Nie określono & $\begin{array}{l}{[95]} \\
{[38]}\end{array}$ \\
\hline MM & PIM2 & Nie określono & {$[50]$} \\
\hline CML & $P I M 1 / 2 / 3$ & Nie określono & [96] \\
\hline
\end{tabular}

CLL (chronic lymphocytic leukaemia) - przewlekła białaczka limfocytowa; MCL (mantle cell lymphoma) — chłoniak z komórek płaszcza; DLBCL (diffuse large B-cell lymphoma) - chłoniak rozlany z dużych komórek B; FL (follicular lymphoma) — chłoniak grudkowy; PMBCL (primary mediastinal large B-cell lymphoma) - chłoniak śródpiersia z dużych komórek B; cHL (classical Hodgkin lymhoma) — chłoniak Hodgkina, AML (acute myelogenous leukemia) — ostra białaczka szpikowa; MM (multiple myeloma) - szpiczak plazmocytowy; CML (chronic myelogenous leukemia) — przewlekła białaczka szpikowa

onkogennych aberracji strukturalnych. Inhibitory kinaz PIM w modelach przedklinicznych wykazują wysoką aktywność $\mathrm{w}$ modelach in vitro i in vivo. $\mathrm{W}$ blastach białaczkowych inkubowanych $z$ inhibitorem pan-PIM następuje spadek aktywności czynników transkrypcyjnych zależnych od PIM - w tym c-MYC i STAT5, zahamowanie fosforylacji H3S10 oraz zahamowanie translacji zależnej od czapeczki mRNA (spadek aktywności 4E-BP1, białka rybosomalnego S6 oraz spadek aktywności mTOR, zależny od wpływu kinaz PIM na białko PRAS40) [38, 72-74]. W komórkach AML obserwowano również spadek fosforylacji S112 BAD i spadek ekspresji antyapoptotycznego białka MCL1 (zależnego od zahamowania translacji). W konsekwencji inhibitory kinaz PIM, w tym SGI-1776, AZD1208, LGB321, powodują blokadę cyklu komórkowego i prowadzą do apoptozy blastów AML [38, 72-74]. Największą wrażliwość na inhibitory PIM wykazują komórki białaczkowe charakteryzujące się wysoką ekspresją aktywnej formy czynnika transkrypcyjnego STAT5 (fosfo-Y694/699) i ekspresją białka regulowanego przez STAT5, powierzchniowego receptora IL-2, białka ILR2A (CD25) [38]. Wymuszona ekspresja aktywnego STAT5 prowadzi do zwiększenia ekspresji CD25 i zwiększenia wrażliwości na inhibitory PIM. Do aktywacji STAT5 dochodzi m.in. w trakcie nabywania przez blasty białaczkowe oporności na cytostatyki, np. cytarabinę [38]. Komórki linii AML KG1 oporne na cytarabinę charakteryzowały się wyższą ekspresją CD25 niż komórki kontrolne (wrażliwe na ten cytostatyk) i charakteryzowały się istotnie wyższą wrażliwością na inhibitory PIM. W komórkach odpowiadających na zahamowanie tych kinaz obserwowano uniwersalny spadek fosforylacji c-MYC, zwiększoną jego ubikwitynację i degradację [38]. Ponieważ STAT5 ic-MYC odgrywają istotną rolę w podtrzymywaniu, ekspansji i samoodnowie prawidłowych i białaczkowych komórek macierzystych, obserwacje te mogą sugerować, że inhibitory PIM - poprzez wyłączenie tych czynników transkrypcyjnych - uderzają w program transkrypcyjny odpowiedzialny za fenotypowe i czynnościowe cechy białaczkowej komórki macierzystej. Aktywność STAT5 i ekspresja regulowanego przez ten czynnik powierzchniowego antygenu CD25 mogą ponadto stanowić biomarker wrażliwości na inhibitory pan-PIM. W odróżnieniu od wielu innych kinaz onkogennych będących celem małocząsteczkowych inhibitorów na aktywność kinaz PIM nie wpływają aberracje strukturalne, zatem nie mogą one stanowić klinicznego „binarnego” biomarkera, wskazującego na aktywność bądź brak aktywności kinazy ani stanowić podstawy do stratyfikacji chorych do badania klinicznego (mutacja-aktywność, włączenie leku; brak mutacji — brak aktywności i brak wskazań do włączenia leku). Z tego względu stan powierzchniowej ekspresji CD25 może stanowić bardzo istotny czynnik stratyfikujący w badaniach klinicznych nad racjonalnym zastosowaniem inhibitorów tych kinaz w AML. Jak w przypadku wszelkich zmiennych ciągłych, wykorzystanie ekspresji CD25 wymagać będzie jednak precyzyjnego zdefiniowania punktów odcięcia i dychotomizacji wyników cytometrii przepływowej (brak/ /niska ekspresja versus wysoka ekspresja) oraz standaryzacji dla zapewnienia porównywalności między laboratoriami.

Do badań klinicznych w nowotworach mieloidalnych dotychczas trafiły trzy inhibitory - SGI-1776 (Supergen), którego rozwój ze względu na kardiotoksyczność zakońCzono, INCB053914 (Incyte) oraz LGH447 (Novartis). Badanie I fazy u chorych z AML i MDS wysokiego ryzyka jest obecnie w toku (NCT02078609).

\section{Inhibicja kinaz PIM w nowotworach układu chłonnego}

Od chwili odkrycia roli kinaz PIM w akceleracji nowotworów układu chłonnego inicjowanych przez c-MYC nadekspresję kinaz tej rodziny opisano w wielu nowotworach B-komórkowych. Ekspresję przynajmniej jednej z 3 izoform kinaz PIM obserwuje się w większości chłoniaków DLBCL (diffuse large B-cell lymphoma), FL (follicular lymphoma), CLL 
(chronic lymphocytic leukemia), MCL (mantle cell lymphoma) i PCM (plasma cell myeloma) (tab. II) [80]. W rozlanych chłoniakach z dużych komórek B, chłoniakach grudkowych i chłoniaku Burkitta, locus kinazy PIM1 zawiera mutacje wynikające z zaburzonej hipermutacji somatycznej [81]. Mutacje te występują u ok. 40\% chorych z DLBCL i dotyczą N-końcowej części białka, zawierającej domenę katalityczną i kieszeń wiążącą ATP [81]. Funkcjonalne konsekwencje tych mutacji nie zostały jednak dotychczas wyjaśnione. Ekspresja kinazy PIM1 jest wyższa w agresywnych chłoniakach DLCBL o profilu ekspresji $A B C$ (activated B-cell like) niż w chłoniakach GCB (germinal center B-cell like) i towarzyszy jej obecność aktywnych czynników transkrypcyjnych STAT3 i STAT5 [82]. Jądrowa obecność kinazy PIM1 w DLBCL wiąże się z wyższą aktywnością proliferacyjną komórek DLBCL i wyższym klinicznym stopniem zaawansowania choroby [83]. Zahamowanie kinaz PIM małocząsteczkowym inhibitorem pan-PIM (SEL24-B489) powoduje obniżenie proliferacji oraz indukcję apoptozy w liniach modelowych DLBCL. W komórkach DLBCL inhibicja PIM powoduje obniżenie fosforylacji i aktywności białek zaangażowanych w translację białek: 4EBP1 i S6 oraz destabilizację c-MYC [84]. Ponadto w liniach DLBCL podtypu ABC zahamowaniu PIM towarzyszy spadek transkrypcji licznych genów zależnych od $\mathrm{NF} \kappa \mathrm{B}$, a równoczesna inhibicja osi NFkB przy użyciu inhibitora kinazy Btk ibrutinibu oraz inhibitora pan-PIM (SEL24-B489) powoduje efekt synergii i znaczne spotęgowanie toksyczności [84].

Ekspresja kinazy PIM1 wykazuje ponadto związek z rokowaniem u chorych z chłoniakiem strefy płaszcza (tab. II). Wysoka ekspresja PIM1, oceniana immunohistochemicznie, stanowiła niekorzystny czynnik rokowniczy w zakresie czasu przeżycia wolnego od progresji i całkowitego czasu przeżycia w homogennej grupie wcześniej nieleczonych chorych z MCL, którzy otrzymali intensywną immunochemioterapię, a następnie autologiczny przeszczep komórek krwiotwórczych [85]. Ekspresja PIM1 występuje u ok. 1/2-2/3 chorych z MCL, a obecność PIM1 i PIM2 dotyczy do $90 \%$ chorych [80, 85]. U chorych na MCL z wysoką ekspresją PIM1 lub PIM2 obserwowano również wyższą ekspresję MDM2, ligazy E3 ubikwityny destabilizującej m.in. p53 [67]. Inhibicja kinaz PIM w modelach linii komórkowych MCL in vitro powoduje zahamowanie fosforylacji i aktywności ich substratów, a w konsekwencji zmniejszenie translacji białek, zahamowanie progresji cyklu komórkowego i śmierć komórek [86]. W szczególności zahamowanie kinaz PIM w MCL (zarówno w liniach $M C L$, jak i komórkach pierwotnych) powoduje destabilizację c-MYC i spadek jego ekspresji, a w konsekwencji globalny spadek transkrypcji [86]. Zahamowanie kinaz PIM w komórkach MCL powoduje zmniejszenie translacji „słabych" transkryptów, w tym MCL1. Stopień zahamowania transkrypcji i translacji w komórkach MCL był w tych badaniach wprost proporcjonalny do nasilenia apoptozy, co wskazuje, że upośledzenie tych fundamentalnych procesów komórkowych jest głównym mechanizmem toksyczności pan-inhibitora PIM, SGI-1776 w MCL [86]. Podobne zjawiska związane z toksycznością występują wskutek inaktywacji kinaz PIM poprzez interferencję RNA, co potwierdza specyficzność działania inhibitorów małocząsteczkowych.

Pośród trzech izoform PIM najwyższy poziom ekspresji w komórkach przewlekłej białaczki limfocytowej (CLL) obserwowano dla kinazy PIM2. Ponadto wyższy poziom ekspresji PIM2 obserwowano u chorych w stadium zaawansowania Rai 3-4 oraz u chorych opornych na pierwszą linię leczenia [87]. W komórkach CLL z nadekspresją PIM receptor CXCR4 jest hiperfosforylowany (S339), a inhibicja lub genetyczne wyłączenie kinazy PIM1 powoduje spadek fosforylacji tej seryny, spadek powierzchniowej ekspresji CXCR4 oraz mniejsze natężenie sygnału zależnego od tego receptora w komórkach CLL [54]. Komórki białaczkowe po zahamowaniu CXCR4 wykazywały obniżoną zdolność do zasiedlania nisz szpikowych i śledziony. Poza regulacją receptora CXCR4 kinazy PIM mogą także wspierać migrację komórek CLL, wpływając na aktywność negatywnych regulatorów kinazy mTOR — PRAS40 oraz TSC2 [87]. Blokada kinaz PIM w CLL może zatem prowadzić do uwolnienia komórek z cytoprotekcyjnego mikrośrodowiska węzłowego i szpikowego i zwiększać wrażliwość komórek na działanie leków cytotoksycznych. W odróżnieniu od kinazy PIM1, regulującej głównie migrację, kinazy PIM2 i PIM3 w CLL działają antyapoptotycznie [55]. Zastosowanie inhibitora pan-PIM (SEL24-B489) w pierwotnych komórkach CLL hamuje translację oraz indukuję apoptozę [87].

W komórkach szpiczaka plazmocytowego najwyższą ekspresję spośród kinaz PIM wykazuje PIM2 [17, 50]. Ekspresja kinazy PIM2 w PCM jest regulowana siecią powiązań parakrynnych z mikrośrodowiskiem i prowadzi do zwiększenia oporności nowotworowych plazmocytów na czynniki proapoptotyczne, w tym leki [17]. W modelach komórkowych in vitro jej obecność jest niezbędna dla podtrzymania proliferacji [50]. Farmakologiczne wyłączenie aktywności kinaz PIM (LGB321) prowadzi do zahamowania wzrostu komórek w modelach in vitro i in vivo (ksenoprzeszczepach linii komórek PCM) [50]. Biochemicznym podłożem tych zjawisk jest wpływ kinazy PIM2 na aktywność szlaku mTORC1, zależny od fosforylacji Ser1798, inhibitora szlaku mTORC1, białka TSC2 [50]. Obok wpływu na translację mTORC1 jest kluczowym regulatorem autofagii, zatem spadek aktywności tego kompleksu spowodowany działaniem pan-inhibitora PIM, SGI-1776, może tłumaczyć indukcję tego procesu i działanie cytodestrukcyjne również w tym mechanizmie [51]. Nadekspresja PIM2 dotyczy jednak nie tylko nowotworowych plazmocytów, ale również komórek podścieliska i prekursorów osteoblastów, w których aktywność tego enzymu powoduje zahamowanie kościotworzenia [88]. PIM2 w osteoblastach jest indukowana działaniem uwalnianych w PCM cytokin prozapalnych hamujących osteogenezę (TNF $\alpha$, IL3, 
IL-7, TGF- $\beta$ ). Indukowana przez te czynniki aktywność kinazy PIM2 w prekursorach osteoblastów antagonizuje działanie BMP2 (bone morphogenetic protein 2), cytokiny działającej anabolicznie i osteogennie [88]. W konsekwencji zablokowanie PIM2 w tych komórkach zwiększa osteogenezę, a w mysich modelach PCM pan-inhibitor PIM zmniejszał proliferację komórek nowotworowych i skutecznie zapobiegał utracie tkanki kostnej. Z tego względu strategia terapeutyczna ukierunkowana na zahamowanie kinaz PIM w PCM może wywierać działanie plejotropowe dotyczące zarówno komórek nowotworowych, jak i ich mikrośrodowiska, oraz przerywać ich wzajemne powiązania patogenetyczne. Badania kliniczne $z$ udziałem chorych na nowotwory układu chłonnego z zastosowaniem inhibitora pan-PIM LGH447 są w toku (tab. I).

Nadekspresję przynajmniej jednej z trzech izoform PIM obserwowano w komórkach nowotworowych Reed-Sternberga (RS) u ok. 97\% chorych z klasycznym chłoniakiem Hodgkina (classical Hodgkin lymphoma - cHL). W linach modelowych wykazano, iż ekspresja tych kinaz w komórkach RS wynika z konstytutywnej aktywności czynników STAT oraz NFKB. Genetyczne zahamowanie aktywności wszystkich trzech izoform PIM lub zastosowanie inhibitora pan-PIM (SEL24-B489) obniża proliferację oraz indukuje apoptozę komórek RS in vitro oraz in vivo. Inhibicji PIM w linach cHL towarzyszy zahamowanie fosforylacji i aktywności białek 4EBP1 oraz S6, prowadząc w konsekwencji do zmniejszenia translacji białek. W szczególności zahamowanie PIM w liniach RS obniża aktywność czynników transkrypcyjnych STAT3/5 oraz NF $\kappa$ B-p65, co skutkuje obniżeniem ekspresji białek RelB i Bfl-1, ale także licznych cytokin i chemokin, w tym IL-8 i CCL5, odpowiedzialnych za powstawanie charakterystycznego mikrośrodowiska $\mathrm{w} \mathrm{cHL}$. W badaniach wykazano również, iż kinazy PIM mogą odgrywać istotną rolę w kształtowaniu immunosupresyjnego charakteru mikrośrodowiska, ponieważ inhibicja PIM powoduje spadek ekspresji białek immunomodulujących PD-L1 oraz galektyny-1 in vitro oraz in vivo [89].

\section{Perspektywy}

Z uwagi na szerokie spektrum substratów wpływających na ważne funkcje biologiczne komórek nowotworowych oraz współdziałanie z innymi onkogenami kinazy PIM stanowią obiecujący cel terapeutyczny. Dane z modeli przedklinicznych in vitro i in vivo z użyciem małocząsteczkowych inhibitorów potwierdzają potencjał strategii terapeutycznych ukierunkowanych na kinazy tej grupy. Badania te pozwoliły również zdefiniować kluczowe szlaki sygnałowe i białka, których aktywność ulega zmianie wskutek wyłączenia PIM, w tym translację, transkrypcję, apoptozę i cykl komórkowy. Kinazy PIM wpływają na aktywność tych szlaków w nieco odmienny sposób niż ich „kanoniczne” regulatory, co wskazuje na duży potencjał racjonalnego łączenia tych inhibitorów z innymi modulatorami tych szlaków, na przykład dane eksperymentalne potwierdzają synergię między inhibitorami mTOR i PIM w zakresie zahamowania translacji, a badania kliniczne I/II fazy nad połączeniem inhibitorów szlaku AKT/ /mTOR i inhibitora kinaz PIM są w toku. Poprzez wpływ na szlak p53 i białko BAD inhibitory PIM mogą uwrażliwiać komórki nowotworowe na klasyczne chemioterapeutyki, a pierwsze obserwacje również potwierdzają prawidłowość tych założeń. Jak w przypadku każdej terapii celowanej, racjonalne stosowanie kliniczne inhibitorów kinaz PIM wymagać będzie wskazania populacji chorych, u których stosowanie leku będzie uzasadnione. Z uwagi na molekularny mechanizm regulacji aktywności kinaz PIM dla większości nowotworów w chwili obecnej nie dysponujemy żadnym racjonalnym biomarkerem, a w szczególności brakuje biomarkera „,binarnego", który pozwalałby w sposób jednoznaczny określić wskazania dla tej grupy cząstek. W większości badań pojęcia „wysokiej”i „,niskiej" ekspresji są arbitralne i niemożliwe do wystandaryzowania i zastosowania w praktyce klinicznej, a w szczególności w ramach badań klinicznych. Z tego względu obecnie trwają intensywne poszukiwania biomarkerów, które wskazują na aktywność kinaz PIM w sposób pośredni, a jednocześnie uwzględniają kontekst biologiczny aktywności i sposobu ich regulacji. Pierwszym sukcesem w tym zakresie może okazać się ekspresja CD25 w AML. Trwające i przyszłe badania kliniczne, zwłaszcza te oparte o racjonalną, rygorystyczną stratyfikację chorych z zastosowaniem biomarkerów odzwierciedlających kontekst biologiczny aktywności tych kinaz, mogą wprowadzić do praktyki tę nową klasę leków.

\section{Prof. dr hab. n. med. Przemysław Juszczyński}

Zakład Hematologii Eksperymentalnej

Instytut Hematologii i Transfuzjologii

ul. Indiry Gandhi 14, 02-776 Warszawa

e-mail:pjuszczynski@ihit.waw.pl

Otrzymano i przyjęto do druku: 24 listopada 2015 r.

\section{Piśmiennictwo}

1. Nawijn MC, Alendar A, Berns A. For better or for worse: the role of Pim oncogenes in tumorigenesis. Nat Rev Cancer 2011:11:23-34.

2. Cuypers HT, Selten G, Quint W i wsp. Murine leukemia virus-induced T-cell lymphomagenesis: integration of proviruses in a distinct chromosomal region. Cell 1984; 37: 141-150.

3. van der Lugt NM, Domen J, Verhoeven E i wsp. Proviral tagging in E mu-myc transgenic mice lacking the Pim-1 proto-oncogene leads to compensatory activation of Pim-2. EMBO J 1995; 14: 2536-2544.

4. Mikkers $\mathrm{H}$, Allen J, Knipscheer P i wsp. High-throughput retroviral tagging to identify components of specific signaling pathways in cancer. Nat Genet 2002; 32: 153-159.

5. van Lohuizen $M$, Verbeek $S$, Krimpenfort $P$ i wsp. Predisposition to lymphomagenesis in pim-1 transgenic mice: cooperation with c-myc and $\mathrm{N}$-myc in murine leukemia virus-induced tumors. Cell 1989; 56: 673-682.

6. Selten G, Cuypers HT, Zijlstra M i wsp. Involvement of c-myc in MuLV-induced T cell lymphomas in mice: frequency and mechanisms of activation. EMBO J 1984; 3: 3215-3222.

7. Verbeek S, van Lohuizen M, van der Valk M, Domen J, Kraal G, Berns A Mice bearing the $E$ mu-myc and $E$ mu-pim-1 transgenes develop preB-cell leukemia prenatally. Mol Cell Biol 1991; 11: 1176-1179. 
8. Baron BW, Anastasi J, Hyjek EM i wsp. PIM1 gene cooperates with human BCL6 gene to promote the development of lymphomas. Proc Natl Acad SciU SA. 2012; 109: 5735-5739.

9. Chen JL, Limnander A, Rothman PB. Pim-1 and Pim-2 kinases are required for efficient pre-B-cell transformation by $\mathrm{v}$-Abl oncogene. Blood 2008; 111: 1677-1685.

10. Mikkers H, Nawijn M, Allen J i wsp. Mice deficient for all PIM kinases display reduced body size and impaired responses to hematopoietic growth factors. Mol Cell Biol 2004; 24: 6104-6115.

11. Domen J, Von Lindern M, Hermans A i wsp. Comparison of the human and mouse PIM-1 cDNAs: nucleotide sequence and immunological identification of the in vitro synthesized PIM-1 protein. Oncogene Res 1987; 1: 103-112.

12. Hoover DS, Wingett DG, Zhang J i wsp. Pim-1 protein expression is regulated by its 5 -untranslated region and translation initiation factor elF-4E. Cell Growth Differ 1997; 8: 1371-1380.

13. Fox CJ, Hammerman PS, Cinalli RM i wsp. The serine/threonine kinase Pim-2 is a transcriptionally regulated apoptotic inhibitor. Genes Dev 2003; 17: 1841-1854.

14. Qian KC, Wang L, Hickey ER i wsp. Structural basis of constitutive activity and a unique nucleotide binding mode of human Pim-1 kinase. J Biol Chem 2005; 280: 6130-6137.

15. Woodland RT, Fox CJ, Schmidt MR i wsp. Multiple signaling pathways promote $B$ lymphocyte stimulator dependent B-cell growth and survival. Blood 2008; 111: 750-760.

16. Zhu N, Ramirez LM, Lee RL i wsp. CD40 signaling in B cells regulates the expression of the Pim-1 kinase via the NF-kappa B pathway. J Immunol 2002; 168: 744-754.

17. Asano J, Nakano A, Oda A i wsp. The serine/threonine kinase Pim-2 is a novel anti-apoptotic mediator in myeloma cells. Leukemia 2011; 25: $1182-1188$

18. Miura O, Miura Y, Nakamura N i wsp. Induction of tyrosine phosphorylation of Vav and expression of Pim-1 correlates with Jak2-mediated growth signaling from the erythropoietin receptor. Blood 1994; 84: 4135-4141.

19. Matikainen S, Sareneva T, Ronni Ti wsp. Interferon-alpha activates multiple STAT proteins and upregulates proliferation-associated IL-2Ralpha, c-myc, and pim-1 genes in human T cells. Blood 1999; 93: 1980-1991.

20. Kim KT, Baird K, Ahn JY i wsp. Pim-1 is up-regulated by constitutively activated FLT3 and plays a role in FLT3-mediated cell survival. Blood 2005; 105: 1759-1767.

21. Mizuki M, Schwable J, Steur C i wsp. Suppression of myeloid transcription factors and induction of STAT response genes by AML-specific Flt3 mutations. Blood 2003; 101: 3164-3173.

22. Nieborowska-Skorska M, Hoser G, Kossev P i wsp. Complementary functions of the antiapoptotic protein $\mathrm{A} 1$ and serine/threonine kinase pim-1 in the BCR/ABL-mediated leukemogenesis. Blood 2002; 99:4531-4539.

23. Zhao Y, Hamza MS, Leong HS i wsp. Kruppel-like factor 5 modulates p53-independent apoptosis through Pim1 survival kinase in cancer cells. Oncogene 2008; 27: 1-8.

24. Forshell LP, LiY, Forshell TZ i wsp. The direct Myc target Pim 3 cooperates with other Pim kinases in supporting viability of Myc-induced B-cell lymphomas. Oncotarget 2011; 2: 448-460.

25. Kim O, Jiang T, Xie Y i wsp. Synergism of cytoplasmic kinases in IL6-induced ligand-independent activation of androgen receptor in prostate cancer cells. Oncogene 2004; 23: 1838-1844.

26. Bullock AN, Debreczeni J, Amos AL i wsp. Structure and substrate specificity of the Pim-1 kinase. J Biol Chem 2005; 280: 41675-41682.

27. Shay KP, Wang Z, Xing PX i wsp. Pim-1 kinase stability is regulated by heat shock proteins and the ubiquitin-proteasome pathway. Mol Cancer Res 2005; 3: 170-181.

28. Losman JA, Chen XP, Vuong BQ i wsp. Protein phosphatase $2 \mathrm{~A}$ regulates the stability of Pim protein kinases. J Biol Chem 2003; 278: 4800-4805.

29. Ma J, Arnold HK, Lilly MB i wsp. Negative regulation of Pim-1 protein kinase levels by the B56beta subunit of PP2A. Oncogene 2007; 26: 5145-5153.

30. Mizuno K, Shirogane T, Shinohara A i wsp. Regulation of Pim-1 by Hsp90. Biochem Biophys Res Commun 2001; 281: 663-669.

31. Brault L, Gasser C, Bracher F i wsp. PIM serine/threonine kinases in the pathogenesis and therapy of hematologic malignancies and solid cancers. Haematologica 2010; 95: 1004-1015.

32. Morishita D, Katayama R, Sekimizu K i wsp. Pim kinases promote cell cycle progression by phosphorylating and down-regulating p27Kip1 at the transcriptional and posttranscriptional levels. Cancer Res 2008; 68: 5076-5085.
33. Hammerman PS, Fox CJ, Cinalli RM i wsp. Lymphocyte transformation by Pim-2 is dependent on nuclear factor-kappaB activation. Cancer Res 2004; 64: 8341-8348.

34. Nihira K, Ando Y, Yamaguchi T i wsp. Pim-1 controls NF-kappaB signalling by stabilizing RelA/p65. Cell Death Differ 2010; 17: 689-698.

35. Zhang Y, Wang Z, Li X i wsp. Pim kinase-dependent inhibition of C-Myc degradation. Oncogene 2008; 27: 4809-4819.

36. Leverson JD, Koskinen PJ, Orrico FC i wsp. Pim-1 kinase and p100 cooperate to enhance c-Myb activity. Mol Cell 1998; 2: 417-425.

37. Aho TL, Sandholm J, Peltola KJ i wsp. Pim-1 kinase phosphorylates RUNX family transcription factors and enhances their activity. BMC Cell Biol 2006; 7: 21.

38. Guo Z, Wang A, Zhang W i wsp. PIM inhibitors target CD25-positive AML cells through concomitant suppression of STAT5 activation and degradation of MYC oncogene. Blood 2014; 124: 1777-1789.

39. Zippo A, De Robertis A, Serafini R i wsp. PIM1-dependent phosphorylation of histone $\mathrm{H} 3$ at serine 10 is required for MYC-dependent transcriptional activation and oncogenic transformation. Nat Cell Biol 2007; 9: 932-944.

40. Zippo A, Serafini R, Rocchigiani M i wsp. Histone crosstalk between $\mathrm{H} 3 \mathrm{~S} 10 \mathrm{ph}$ and H4K16ac generates a histone code that mediates transcription elongation. Cell 2009; 138: 1122-1136.

41. Rahl PB, Lin CY, Seila AC i wsp. c-Myc regulates transcriptional pause release. Cell 2010; 141:432-445.

42. Chang M, Kanwar N, Feng E i wsp. PIM kinase inhibitors downregulate STAT3(Tyr705) phosphorylation. Mol Cancer Ther 2010; 9: 2478-2487.

43. Isaac M, Siu A, Jongstra J. The oncogenic PIM kinase family regulates drug resistance through multiple mechanisms. Drug Resist Updat 2011; 14: 203-211.

44. Amaravadi R,Thompson CB. The survival kinases Akt and Pim as potential pharmacological targets. J Clin Invest 2005; 115: 2618-2624.

45. Fox CJ, Hammerman PS.Thompson CB. The Pim kinases control rapamycin-resistant T cell survival and activation. J Exp Med 2005; 201: 259-266.

46. De Benedetti A, Graff JR. elF-4E expression and its role in malignancies and metastases. Oncogene 2004; 23: 3189-3199.

47. Culjkovic B, Topisirovic I, Skrabanek L i wsp. elF4E is a central node of an RNA regulon that governs cellular proliferation. J Cell Biol 2006; 175: 415-426.

48. Janku F, McConkey DJ, Hong DS i wsp. Autophagy as a target for anticancer therapy. Nat Rev Clin Oncol 2011; 8: 528-539.

49. Zhang F, Beharry ZM, Harris TE i wsp. PIM1 protein kinase regulates PRAS40 phosphorylation and mTOR activity in FDCP1 cells. Cancer Biol Ther 2009; 8: 846-853.

50. Lu J, Zavorotinskaya T, Dai Y i wsp. Pim2 is required for maintaining multiple myeloma cell growth through modulating TSC2 phosphorylation. Blood 2013; 122: 1610-1620.

51. Cervantes-Gomez F, Chen LS, Orlowski RZ i wsp. Biological effects of the Pim kinase inhibitor, SGI-1776, in multiple myeloma. Clin Lymphoma Myeloma Leuk 2013; 13 Suppl 2: S317-329.

52. An N, Kraft AS, Kang Y. Abnormal hematopoietic phenotypes in Pim kinase triple knockout mice. J Hematol Oncol 2013; 6: 12

53. Grundler R, Brault L, Gasser C i wsp. Dissection of PIM serine/threonine kinases in FLT3-ITD-induced leukemogenesis reveals PIM1 as regulator of CXCL12-CXCR4-mediated homing and migration. J Exp Med 2009; 206: 1957-1970.

54. Decker S, Finter J, Forde AJ i wsp. PIM kinases are essential for chronic lymphocytic leukemia cell survival (PIM2/3) and CXCR4-mediated microenvironmental interactions (PIM1). Mol Cancer Ther 2014; 13: 1231-1245.

55. Peled A,Tavor S. Role of CXCR4 in the pathogenesis of acute myeloid leukemia. Theranostics 2013; 3: 34-39.

56. Uy GL, Rettig MP, Motabi IH i wsp. A phase $1 / 2$ study of chemosensitization with the CXCR4 antagonist plerixafor in relapsed or refractory acute myeloid leukemia. Blood 2012; 119: 3917-3924.

57. Cen B, Xiong Y, Song JH i wsp. The Pim-1 protein kinase is an important regulator of MET receptor tyrosine kinase levels and signaling. Mol Cell Biol 2014; 34: 2517-2532.

58. Santio NM, Vahakoski RL, Rainio EM i wsp. Pim-selective inhibitor DHPCC-9 reveals Pim kinases as potent stimulators of cancer cell migration and invasion. Mol Cancer 2010; 9: 279.

59. Mochizuki T, Kitanaka C, Noguchi Ki wsp. Physical and functional interactions between Pim-1 kinase and Cdc25A phosphatase. Implications for the Pim-1-mediated activation of the c-Myc signaling pathway. J Biol Chem 1999; 274: 18659-18666. 
60. Bachmann M, Kosan C, Xing PX i wsp. The oncogenic serine/threonine kinase Pim-1 directly phosphorylates and activates the G2/M specific phosphatase Cdc25C. Int J Biochem Cell Biol 2006; 38: 430-443.

61. Wang Z, Bhattacharya N, Mixter PF i wsp. Phosphorylation of the cell cycle inhibitor p21Cip1/WAF1 by Pim-1 kinase. Biochim Biophys Acta 2002; 1593: 45-55.

62. Danial NN. BAD: undertaker by night, candyman by day. Oncogene 2008; 27 Suppl 1: S53-70.

63. Yan B, Zemskova M, Holder S i wsp. The PIM-2 kinase phosphorylates $B A D$ on serine 112 and reverses BAD-induced cell death. J Biol Chem 2003; 278: 45358-45367.

64. AhoTL, Sandholm J, Peltola KJi wsp. Pim-1 kinase promotes inactivation of the pro-apoptotic Bad protein by phosphorylating it on the Ser112 gatekeeper site. FEBS Lett 2004; 571: 43-49.

65. Macdonald A, Campbell DG, Toth R i wsp. Pim kinases phosphorylate multiple sites on Bad and promote 14-3-3 binding and dissociation from Bcl-XL. BMC Cell Biol 2006; 7: 1.

66. Danial N.N, Gramm C.F, Scorrano L i wsp. BAD and glucokinase reside in a mitochondrial complex that integrates glycolysis and apoptosis. Nature 2003; 424: 952-956.

67. Hogan C, Hutchison C, Marcar L i wsp. Elevated levels of oncogenic protein kinase Pim-1 induce the p53 pathway in cultured cells and correlate with increased Mdm2 in mantle cell lymphoma. J Biol Chem 2008; 283: 18012-18023.

68. Domen J, van der Lugt NM, Acton D i wsp. Pim-1 levels determine the size of early B lymphoid compartments in bone marrow. J Exp Med 1993; 178: 1665-1673.

69. Domen J, van der Lugt NM, Laird PW i wsp. Impaired interleukin-3 response in Pim-1-deficient bone marrow-derived mast cells. Blood 1993; 82: 1445-1452.

70. Vlacich G, Nawijn MC, Webb GC i wsp. Pim3 negatively regulates glucose-stimulated insulin secretion. Islets 2010; 2: 308-317.

71. Alvarado Y, Giles FJ, Swords RT. The PIM kinases in hematological cancers. Expert Rev Hematol 2012; 5: 81-96.

72. Garcia PD, Langowski JL, Wang Y i wsp. Pan-PIM kinase inhibition provides a novel therapy for treating hematologic cancers. Clin Cancer Res 2014; 20: 1834-1845.

73. Keeton EK, McEachern K, Dillman KS i wsp. AZD1208, a potent and selective pan-Pim kinase inhibitor, demonstrates efficacy in preclinical models of acute myeloid leukemia. Blood 2014; 123: 905-913.

74. Chen LS, Redkar S, Taverna P i wsp. Mechanisms of cytotoxicity to Pim kinase inhibitor, SGI-1776, in acute myeloid leukemia. Blood 2011; 118: 693-702.

75. Hu YL, Passegue E, Fong Si wsp. Evidence that the Pim 1 kinase gene is a direct target of HOXA9. Blood 2007; 109: 4732-4738.

76. Agrawal S, Koschmieder S, Baumer N i wsp. Pim2 complements Flt3 wild-type receptor in hematopoietic progenitor cell transformation. Leukemia 2008; 22: 78-86.

77. Wernig G, Gonneville JR, Crowley BJ i wsp. The Jak2V617F oncogene associated with myeloproliferative diseases requires a functional FERM domain for transformation and for expression of the Myc and Pim proto-oncogenes. Blood 2008; 111: 3751-3759.

78. Adam M, Pogacic V, Bendit M i wsp. Targeting PIM kinases impairs survival of hematopoietic cells transformed by kinase inhibitor-sensitive and kinase inhibitor-resistant forms of Fms-like tyrosine kinase 3 and BCR/ABL. Cancer Res 2006; 66: 3828-3835.
79. Hoover RR, Gerlach MJ, Koh EY i wsp. Cooperative and redundant effects of STAT5 and Ras signaling in BCR/ABL transformed hematopoietic cells. Oncogene 2001; 20: 5826-5835.

80. Schatz JH, Oricchio E, Wolfe AL i wsp. Targeting cap-dependent translation blocks converging survival signals by AKT and PIM kinases in lymphoma. J Exp Med 2011; 208: 1799-1807.

81. Pasqualucci L, Neumeister P, Goossens T i wsp. Hypermutation of multiple proto-oncogenes in B-cell diffuse large-cell lymphomas. Nature 2001; 412: 341-346.

82. Rosenwald A, Wright G, Chan WC i wsp. The use of molecular profiling to predict survival after chemotherapy for diffuse large-B-cell lymphoma. N Engl J Med 2002; 346: 1937-1947.

83. Brault $\mathrm{L}$, Menter T, Obermann EC i wsp. PIM kinases are progression markers and emerging therapeutic targets in diffuse large B-cell lymphoma. Br J Cancer 2012; 107: 491-500.

84. Szydlowski M, Jablonska E, Bialopiotrowicz E i wsp. Inhibition of PIM kinases decreases protein translation and attenuates MYC and NFKB activity in diffuse large B-cell lymphoma cell lines. Hematol Oncol 2015; 33: 233.

85. Hsi ED, Jung SH, Lai Ri wsp. Ki67 and PIM1 expression predict outcome in mantle cell lymphoma treated with high dose therapy, stem cell transplantation and rituximab: a Cancer and Leukemia Group B 59909 correlative science study. Leuk Lymphoma 2008; 49: 2081-2090.

86. Yang Q, Chen LS, Neelapu SS i wsp. Transcription and translation are primary targets of Pim kinase inhibitor SGI-1776 in mantle cell lymphoma. Blood 2012; 120: 3491-3500.

87. Bialopiotrowicz E, Gorniak P, Szydlowski M i wsp. PIM kinases promote chronic lymphocytic leukemia cell survival through a pleiotropic mechanism involving modulation of CXCR4-triggered mTOR pathway. Hematol Oncol 2015; 33: 233.

88. Hiasa M, Teramachi J, Oda A i wsp. Pim-2 kinase is an important target of treatment for tumor progression and bone loss in myeloma. Leukemia 2015; 29: 207-217.

89. Szydlowski M, Bialopiotrowicz E, Jablonska E i wsp. Inhibition of PIM kinases impairs NFKB activity and induces apoptosis in classical Hodgkin lymphoma Reed-Sternberg cell lines. Hematol Oncol 2015; 33: 318.

90. Chen LS, Redkar S, Bearss D i wsp. Pim kinase inhibitor, SGI-1776, induces apoptosis in chronic lymphocytic leukemia cells. Blood 2009; 114:4150-4157.

91. Cohen AM, Grinblat B, Bessler H i wsp. Increased expression of the hPim-2 gene in human chronic lymphocytic leukemia and non-Hodgkin lymphoma. Leuk Lymphoma 2004; 45: 951-955.

92. de Vos S, Krug U, Hofmann WK i wsp. Cell cycle alterations in the blastoid variant of mantle cell lymphoma (MCL-BV) as detected by gene expression profiling of mantle cell lymphoma (MCL) and MCL-BV. Diagn Mol Pathol 2003; 12: 35-43.

93. Gomez-Abad C, Pisonero H, Blanco-Aparicio Ci wsp. PIM2 inhibition as a rational therapeutic approach in B-cell lymphoma. Blood 2011;118:5517-5527.

94. Martelli M, Ferreri AJ, Johnson P. Primary mediastinal large B-cell lymphoma. Crit Rev Oncol Hematol 2008; 68: 256-263.

95. Tamburini J, Green A.S, Bardet V i wsp. Protein synthesis is resistant to rapamycin and constitutes a promising therapeutic target in acute myeloid leukemia. Blood 2009; 114: 1618-1627.

96. Curi DA, Beauchamp EM, Blyth GT i wsp. Pre-clinical evidence of PIM kinase inhibitor activity in BCR-ABL1 unmutated and mutated Philadelphia chromosome-positive $(\mathrm{Ph}+)$ leukemias. Oncotarget 2015; 6 : 33206-33216. 